\title{
PENGARUH KEPEMIMPINAN TRANSFORMASIONAL DAN IKLIM ORGANISASI TERHADAP KINERJA DOSEN DIMEDIASI KOMPETENSI DOSEN DI KABUPATEN JAYAWIJAYA
}

\author{
Nurita Angesti Rahayu ${ }^{1}$, Ida M. Hutabarat ${ }^{2}$, Tanta $^{3}$ \\ ${ }^{1}$ Sekolah Tinggi Keguruan dan Ilmu Pendidikan (STKIP) Kristen Wamena. \\ ${ }^{2,3}$ Magister Manajemen Pendidikan FKIP Universitas Cenderawasih \\ Email: nuritarahayu89@gmail.com
}

\begin{abstract}
Abstrak
Penelitian ini bertujuan untuk menguji pengaruh langsung kepemimpinan transformasional, iklim organisasi, dan kompetensi dosen terhadap kinerja dosen. Menguji pengaruh langsung kepemimpinan transformasional dan iklim organisasi terhadap kompetensi dosen. Selain itu, menguji pengaruh kepemimpinan transformasional melalui kompetensi dosen terhadap kinerja dosen dan menguji iklim organisasi melalui kompetensi dosen terhadap kinerja dosen. Pengujian variabel penelitian menggunakan instrumen berupa kuesioner yang dibagikan kepada dosen dengan menggunakan skala likert 1-5 bergradasi positif dan negatif yang dibagikan kepada 54 sampel dari 117 populasi. Pengambilan sampel menggunakan teknik probability sampling.Tempat penelitian ini di Sekolah Tinggi yang dinaungi oleh LLDIKTI wilayah XIV di Kabupaten Jayawijaya. Penelitian ini menggunakan pendekatan kuantitatif, dengan jenis penelitian eksplanasi. Analisis dalam penelitian ini dengan menggunakan analisis jalur (Path Analisys) dengan bantuan program SPSS versi 21. Hasil penelitian menunjukkan bahwa (1) Terdapat pengaruh kepemimpinan transformasional terhadap kompetensi dosen, (2) Terdapat pengaruh iklim organisasi terhadap kompetensi dosen, (3) Terdapat pengaruh kepemimpinan transformasional terhadap kinerja dosen, (4) Tidak terdapat pengaruh iklim organisasi terhadap kinerja dosen, (5) Terdapat pengaruh kompetensi dosen terhadap kinerja dosen, (6) Tidak terdapat pengaruh kepemimpinan transformasional melalui kompetensi dosen terhadap kinerja dosen, (7) Tidak terdapat pengaruh iklim organisasi melalui kompetensi dosen terhadap kinerja dosen.
\end{abstract}

Kata Kunci: Kepemimpinan Transformasional, Iklim Organisasi, Kompetensi, Kinerja, Jayawijaya

\begin{abstract}
This study aims to examine the direct effect of transformational leadership, organizational climate, and lecturer competence on the performance of lecturers. Examine the direct influence of transformational leadership and organizational climate on the competence of lecturers. In addition, examining the effect of transformational leadership through lecturer competencies on the performance of lecturers and examining the organizational climate through lecturer competencies on the performance of lecturers. Testing the research variables using instruments in the form of questionnaires distributed to lecturers using 1-5 positive and negative graded Likert scales which were distributed to 54 samples from 117 populations. Sampling using using probability sampling techniques. The place of this research is in the High School which is sheltered by the LLDIKTI of the XIV region in Jayawijaya Regency. This study uses a quantitative approach, with the type of explanatory research. The analysis in this study using Path Analysis with the help of the SPSS version 21 program. The results of the study show that (1) There is the influence of
\end{abstract}


transformational leadership on lecturer competency, (2) There is an influence of organizational climate on lecturer competency, (3) There is influence of transformational leadership on lecturer performance, (4) There is no influence of organizational climate on lecturer performance (5) There is an influence of lecturer competency on the performance of lecturers, (6) There is no effect of transformational leadership through lecturer competency on the performance of lecturers, (7) There is no influence of organizational climate through lecturer competency on the performance of lecturers.

Keywords: Transformational Leadership, Organizational Climate, Competency, Performance, Jayawijaya

\section{PENDAHULUAN}

Peran Perguruan Tinggi dirumuskan melalui konsep tri dharma Perguruan Tinggi yang mencangkup pendidikan dan pengajaran, penelitian serta pengabdian kepada masyarakat. Pendidikan dan pengajaran berguna untuk meningkatkan sumber daya manusia, penelitian dapat digunakan untuk mengembangkan ilmu pengetahuan baru dan perantara ilmu pengetahuan untuk dimanfaatkan dalam masyarakat, dan pengabdian kepada masyarakat dapat digunakan untuk meningkatkan potensi maupun kesejahteraan masyarakat. Dengan adanya Perguruan Tinggi yang menjalankan tri darma Perguruan Tinggi suatu daerah dapat diberdayakan. Selain itu, perguruan tinggi dapat menjadi motor penggerak, penyelaras perubahan, dan pengendali perubahan sosial.

Perguruan Tinggi yang berada di Kabupaten Jayawijaya yang dinaungi oleh LLDIKTI Wilayah XIV yaitu STISIP Amal Ilmiah Yapis Wamena, STIPER Petra Baliem Wamena, STIMIK Agamua, STKIP Abdi Wacara, dan STKIP Kristen Wamena. Berdasarkan sumber PDDIKTI Wilayah XIV semua PTS yang ada di Jayawijaya dalam proses akreditasi institusi (http://kelembagaan.ristekdikti.go.id/ind x.php/kopertis-wilayah-xiv-papua-papuabarat/). Selain itu, sumber daya manusia atau dosen masih banyak yang mengajar tidak sesuai dengan bidangnnya dan tidak memenuhi kualifikasi dosen sesuai dengan ketentuan yang telah ditetapkan oleh Kemenristek Dikti. Dari data yang didapat dari setiap Sekolah Tinggi, ada beberapa dosen yang masih memiliki kualifikasi S-1.

Untuk dapat meningkatkan Akreditasi kampus dan program studi, salah satu hal yang dapat dilakukan adalah dengan meningkakan kualitas dosen, baik dari segi kompetensi maupun dari segi kinerja dosen. Undang-Undang RI no 45 tahun 2005, pasal 45 menguraikan bahwa dosen wajib memiliki kualifikasi akademik, sertifikat akademik, sehat jasmani dan rohani, dan mampu mewujudkan tujuan pendidikan nasional. Untuk memenuhi kualifikasi akademik menjadi dosen dapat diperoleh melalui pendidikan tinggi program pascasarjana (S-2) yang terakreditasi sesuai dengan bidang keahlian (UU RI no 45 tahun 2005, pasal 46). Dosen dikatakan memiliki profesionalisme jika memiliki empat standar keprofesionalan seorang dosen yang mencangkup empat kompetensi dosen yaitu kompetensi pedagogik, kompetensi profesional, kompetensi kepribadian, dan kompetensi sosial. Menurut UU RI Nomor 14 Tahun 2005 Pasal 1 ayat 10 kompetensi adalah seperangkat pengetahuan, keterampilan, dan perilaku yang harus 
dimiliki, dihayati, dan dikuasai oleh guru atau dosen dalam melaksanakan tugas keprofesionalan. Dosen bukan saja sekedar pandai dalam menyampaikan materi perkuliahan, namun mereka juga dituntut untuk profesional melakukan penelitian ilmiah dan cerdas dalam pengabdian kepada masyarakat (Arwildayanto, 2012). Agar peran dosen dapat terlaksana diperlukan seorang dosen yang mampu melaksanakan kinerjanya dengan baik. Kinerja dosen akan tampak dalam tanggung jawab dosen saat melakukan tri dharma Perguruan Tinggi yaitu pengajaran, penelitian dan pengabdian kepada masyarakat.

Kompetensi dosen erat kaitannya dengan kinerja dosen. Kinerja dosen adalah prestasi atau kemampuan kerja dosen dalam melaksanakan tugas dan tanggung jawab dosen. Priansa (2014) mengemukakan bahwa kinerja dosen akan tampak dari tanggung jawab dosen dalam menjalankan amanah, profesi, serta moral yang dimiliki dosen tersebut. Dosen merupakan suatu profesi yang memerlukan keahlian dan suatu jabatan yang tidak bisa dilakukan oleh sembarang orang yang tidak terlatih dan yang tidak disiapkan secara khusus untuk melakukan pekerjaan itu (Karwati dan Priansa, 2013).

Keberhasilan dosen dalam melakukan kinerjanya tidak terlepas dari suasana yang mendukung. Suasana yang dirasakan dosen dalam lingkungan kerjanya merupakan iklim organisasi. Wirawan (2007) menjelaskan bahwa iklim organisasi adalah persepsi anggota organisasi baik secara individual maupun kelompok yang secara tetap berhubungan dengan organisasi mengenai apa yang ada atau terjadi di lingkungan internal organisasi secara rutin, yang mempengaruhi sikap, perilaku, kompetensi anggota organisasi yang kemudian menentukan kinerja dosen. Iklim organisasi yang dirasakan dosen secara positif (menyenangkan) akan memberikan tampilan kerja yang baik dan efektif yang akan mempengaruhi pada kinerja dosen.

Selain itu, seorang dosen membutuhkan bimbingan dan arahan dari seorang pemimpin dalam melakukan kinerjanya. Peran seorang pemimpin yang memiliki kepemimpinan yang tepat untuk membimbing, mengarahkan bahkan mengingatkan dosen dapat meningkatkan kompetensi dan kinerja dosen. Dalam hal ini, pemimpin harus menerapkan kepemimpinan yang dapat membuat dosen termotivasi dalam melakukan kinerjanya yaitu dengan kepemimpinan transformasional. Kepemimpinan transformasional akan dapat mempengaruhi kompetensi dan kinerja dosen.

Kinerja dosen akan tampak dalam tanggung jawab dosen saat melakukan tri dharma Perguruan Tinggi yaitu pengajaran, penelitian dan pengabdian kepada masyarakat. Kinerja dosen di Sekolah Tinggi LLDIKTI Wilayah XIV berdasarkan fakta yang diperoleh dari hasil wawancara ditinjau dari tri dharma Perguruan Tinggi yaitu pendidikan dan pengajaran, penelitian, dan pengabdian kepada masyarakat. Untuk masalah pengajaran ditemukan fakta bahwa ketersediaan bahan ajar yang dihasilkan dosen sangat terbatas dalam kuantitas maupun kualitas. Untuk masalah penelitian dan pengabdian kepada masyarakat fakta yang didapatkan menunjukkan bahwa jumlah dosen dalam melaksanakan penelitian baik oleh masing-masing dosen maupun secara berkelompok masih rendah. Yang menjadi pertanyaan peneliti adalah apakah kepemimpinan transformasional, iklim organisasi ataupun kompetensi dosen akan mempengaruhi kinerja dosen. 


\section{KAJIAN LITERATUR}

\subsection{Kepemimpinan Transformasinal}

Pemimpin transformasional memandang nilai-nilai organisasi sebagai nilai luhur yang perlu dirancang dan ditetapkan oleh seluruh staf sehingga para staf mempunyai rasa memiliki dan komitmen (Komariah dan Triatna, 2010). Kepemimpinan transformasional menurut Bass (1990) dalam Luthans (2006) yaitu bahwa kepemimpinan transformasional membawa keadaan menuju kinerja tinggi pada organisasi yang menghadapi tuntutan pembaruan dan perubahan. Kepemimpinan transformasional tidak saja didasarkan pada kebutuhan akan penghargaan diri, tetapi menumbuhkan kesadaran untuk memberikan yang terbaik (Komariah dan Triatna, 2010). Kepemimpinan transformasional merupakan proses menginspirasi dan memberdayakan.

Jadi, Kepemimpinan transformasional adalah pemimpin dalam menginspirasi bawahan untuk dapat melakukan pembaruan dan perubahan. Kepemimpinan transformasional berdasarkan pendapat Bass dan Avolio (1994) dalam Komariah dan Triatna (2010) dibagi menjadi empat dimensi atau 4I yaitu:

1) Idealiced Influence, adalah perilaku yang menghasilkan rasa hormat dan rasa percaya diri dari orang yang dipimpinnya. Selain itu Idealiced Influence, mengandung makna saling berbagi resiko melalui pertimbangan kebutuhan staf diatas kebutuhan pribadi dan perilaku moral secara etis.

2) Inspirational Motivation, dimensi ini tercermin dalam perilaku yang senantiasa menyediakan tantangan bagi pekerjaan yang dilakukan staf dan memperhatikan makna pekerjaan staf. Dalam hal ini pemimpin adalah seorang motivator yang membangkitkan antusiasme dan optimisme staf.
3) Intellectual Stimulation, yaitu pemimpin yang mempraktikkan inovasi-inovasi. Pemimpin senantiasa menggali ide-ide baru dan solusi yang kreatif dari staf serta mendorong staf mempelajari dan mempraktikan pendekatan baru dalam melakukan pekerjaan.

4) Individualized Consideration, yaitu pemimpin yang merefleksikan dirinya sebagai seorang yang penuh perhatian dalam mendengarkan dan menindaklanjuti keluhan, ide, harapanharapan, dan segala masukkan yang diberikan staf.

Menurut Luthans (Triantoro, 2004) pemimpin transformasional memiliki beberapa karakteristik tertentu, yaitu 1) pemimpin mengidentifikasikan dirinya sendiri sebagai agen perubahan, 2) pemimpin mendorong keberanian dan pengambilan resiko, 3) pemimpin percaya pada orangorang, 4) pemimpin dilandasi oleh nilai-nilai, 5) pemimpin adalah seorang pembelajar sepanjang hidup (lifelongs learners), 6) pemimpin memiliki kemampuan untuk mengatasi kompleksitas, ambiguitas, dan ketidakpastian, 7) pemimpin juga adalah seorang pemimpin yang visioner. Dubrin (2005) mengemukakan pemimpin transformasional menetapkan arah baru yang menarik bagi organisasi atau menciptakan masa depan dengan memilih salah satu dari enam metode yang berada untuk melahirkan perubahan, yaitu: 1) mengubah kultur organisasi, 2) meningkatkan kesadaran orang tentang imbalan, 3) membantu orang tidak sekedar mengejar kepentingan diri, 4) membantu orang mencari pemenuhan diri, 5) memberi pemahaman kepada orang lain tentang keadaan urgen, 6) mengejar kejayaan. 


\subsection{Iklim Organisasi}

Tagiuri dan Letwin mengungkapkan bahwa iklim organisasi merupakan kualitas lingkungan internal organisasi yang secara relatif berlangsung, dialami oleh anggota organisasi, dan mempengaruhi perilaku mereka (Wirawan, 2007). Iklim organisasi adalah serangkaian perasaan dan persepsi yang dapat berubah dari waktu ke waktu atau dari pegawai yang satu ke pegawai yang lain (Sunyoto, 2013). Wirawan (2007:122) menjelaskan bahwa iklim organisasi adalah persepsi anggota organisasi dan tetap berhubungan dengan organisasi mengenai apa yang ada atau terjadi di lingkungan internal organisasi secara rutin, yang mempengaruhi sikap dan perilaku organisasi dan kinerja anggota organisasi. Robert Stringer dalam Wirawan (2007) membagi dimensi iklim organisasi sebagai berikut:

1) Struktur (Structure), merefleksikan perasaan organisasi secara baik dan mempunyai peran dan tanggung jawab yang jelas dalam lingkungan organisasi.

2) Standar-standar (Standards), mengukur perasaan tekanan untuk meningkatkan kinerja dan derajat kebanggaan yamg dimiliki oleh anggota organisasi dalam melakukan pekerjaan dengan baik.

3) Tanggung jawab (Responsibility), merefleksikan perasaan karyawan bahwa mereka menjadi "bos untuk diri sendiri" dan tidak memerlukan keputusannya dilegitimasi oleh anggota organisasi lainnya.

4) Penghargaan

(Recognition), mengindikasikan bahwa anggota organisasi merasa dihargai jika mereka dapat menyelesaikan tugas secara baik. Penghargaan merupakan ukuran atas penyelesaian pekerjaan.

5) Dukungan (Support), perasaan percaya dan saling mendukung yang terus berlangsung diantara anggota kelompok kerja.

6) Komitmen (Commitment), perasaan bangga anggota terhadap organisasinya dan derajat keloyalan terhadap pencapaian tujuan organisasi.

\subsection{Kompetensi Dosen}

Kompetensi menurut Musfah (2011) adalah kemampuan mewujudkan sesuatu sesuai dengan tugas yang diberikan kepada seseorang. Kompetensi adalah kemampuan untuk melaksanakan atau melakukan suatu pekerjaan atau tugas yang dilandasi atas keterampilan dan pengetahuan serta didukung oleh sikap kerja yang dituntut oleh pekerjaan tersebut (Wibowo, 2007). Berdasarkan uraian diatas, kompetensi dosen adalah kemampuan yang dimiliki dosen untuk menunjang kinerja dosen dalam tri dharma Perguruan Tinggi. Kompetensi diperoleh melalui pendidikan, pelatihan, dan belajar mandiri dengan memanfaatkan sumber belajar (Musfah, 2011). Kompetensi dosen meliputi kompetensi pedagogik, kompetensi professional, kompetensi sosial dan kompetensi kepribadian.

\subsection{Kinerja Dosen}

Kinerja dapat ditafsirkan sebagai arti penting suatu pekejaan, tingkat keterampilan yang diperlukan, kemajuan dan tingkat penyelesaian dari suatu pekerjaan (Karwati dan Priansa, 2013). Sementara Priansa (2014) mengemukakan kinerja merupakan hasil kerja pegawai dalam lingkup tanggung jawabnya. Dari berbagai pendapat yang ada, kinerja adalah pencapaian dari suatu pekerjaan yang menjadi tanggung jawabnya. Kinerja dosen tampak dari tanggung jawab dalam menjalankan amanah, profesi, serta moral yang dimilikinya (Priansa, 2014). Kinerja dosen dapat ditunjukkan dari seberapa besar kompetensi-kompetensi 
dipenuhi (Supardi, 2013). Kinerja dosen mencakup tri dharma Perguruan Tinggi yaitu pendidikan dan pengajaran, penelitian serta pengabdian kepada masyarakat.

\section{METODE PENELITIAN}

Penelitian ini menggunakan pendekatan kuantitatif, dengan jenis penelitian ekplanasi. Penelitian ini dilakukan di Sekolah Tinggi LLDIKTI Wilayah XIV Kabupaten Jayawijaya yang terdiri dari STKIP Abdi Wacana Wamena, Sekolah Tinggi Ilmu Pertanian (STIPER) Petra Baliem Wamena, STKIP Kristen Wamena, STISIP Amal Ilmiah Yapis Wamena, STIMIK Agamua Wamena Papua. Jumlah populasi dalam penelitian ini yaitu 117 dosen dan jumlah sampel 54 dosen. Pengambilan sampel mengunakan rumus dari Taro Yamane dengan menggunakan teknik probability sampling. Sumber data dalam penelitian ini adalah data sekunder dan data primer. Data primer diperoleh dengan menyebarkan instrumen penelitian berupa kuesioner yang memiliki gradiasi positif dan negatif dengan menggunakan skala likert 1-5. Analisis data yang digunakan dengan analisis jalur dengan program SPSS versi 21 . Sebelum menganalisis data, peneliti melakukan uji prasyarat data dengan uji asumsi klasik (Uji normalitas data, uji linearitas, uji multikolinearitas, uji heterokedastisitas).

\section{HASIL DANPEMBAHASAN}

\subsection{Kepemimpinan Transformasional} terhadap Kompetensi Dosen

Diketahui bahwa nilai signifikansi kepemimpinan transformasional terhadap kompetensi dosen pada taraf kepercayaan $95 \%$ sebesar 0,040 .

\section{Tabel 1}

Uji Regresi Kepemimpinan Transformasional Terhadap Kompetensi Dosen

Coefficients $^{\mathrm{a}}$

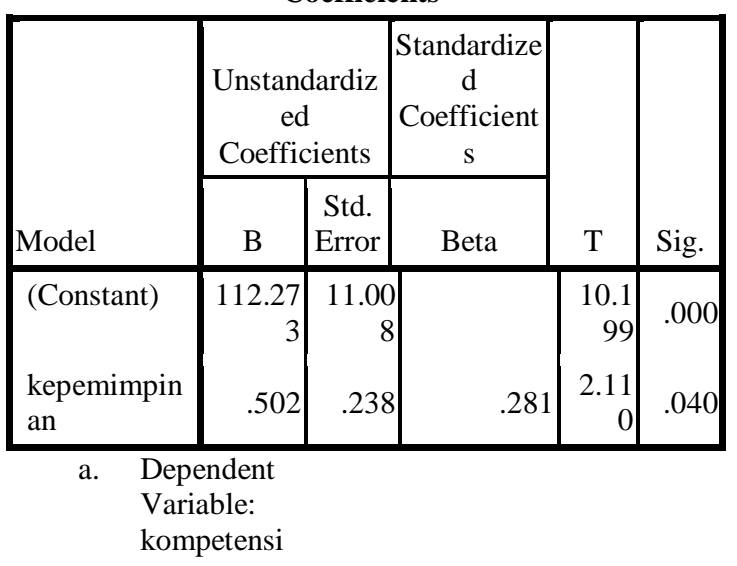

Model Summary

\begin{tabular}{|l|r|r|r|r|}
\hline & & & \multicolumn{1}{|c|}{$\begin{array}{c}\text { Std. } \\
\text { Error of } \\
\text { the } \\
\text { Estimat } \\
\mathrm{e}\end{array}$} \\
\hline 1 & $\mathrm{R}$ & $\mathrm{R}$ Square & $\begin{array}{c}\text { Adjusted R } \\
\text { Square }\end{array}$ & \multicolumn{1}{c|}{$\begin{array}{c}11.2169 \\
0\end{array}$} \\
\hline
\end{tabular}

a. Predictors: (Constant), kepemimpinan

Sumber : Data Primer, diolah 2019

Hal ini menunjukkan nilai $\mathrm{Sig}=0,040<\alpha=0,05$. Dengan demikian $\mathrm{H}_{0}$ ditolak yang berarti terdapat pengaruh signifikan kepemimpinan transformasional terhadap kompetensi dosen. Besarnya keeratan hubungan kepemimpinan transformasional terhadap kompetensi dosen sebesar 0,281 yang berarti hubungan lemah. Besarnya pengaruh kepemimpinan transformasional terhadap kompetensi dosen dapat dilihat dari besarnya nilai adjusted $R$ square yang terdapat pada tabel model summery yaitu sebesar 0,061 .

Hal ini menunjukkan bahwa kontribusi atau sumbangan pengaruh kepemimpinan transformasional terhadap kompetensi dosen adalah sebesar 6,1\%, sementara sisanya $93,9 \%$ merupakan kontribusi dari variabel-variabel lain. Berarti, 
baik tidaknya kepemimpinan transformasional berpengaruh terhadap baik tidaknya kompetensi dosen. Hal ini sejalan dengan penelitian yang dilakukan Baharun (2017) yang menyatakan Kepala Sekolah yang memiliki kepemimpinan transformasional memiliki peluang besar untuk meningkatkan kompetensi guru di madrasah agar sesuai dengan standar yang ditetapkan oleh pemerintah.

Kepemimpinan transformasional ketua pada dasarnya sudah dirasakan dosen, namun belum maksimal. Untuk memaksimalkan kompetensi dosen, ketua perlu mempengaruhi dan membangkitkan antusiasme dan optimisme dari dosen. Antusias dan optimis perlu dimiliki dosen dalam meningkatkan kompetensi dosen karena antusias dan optimis adalah salah satu sikap dan keyakinan yang dimiliki seseorang untuk mencapai tujuannya.

Jika ketua mampu meningkatkan serta membangkitkan antusiasme dan optimisme dosen dapat dipastikan kompetensi dosen juga akan meningkat. Selain itu ketua dapat menggali ide-ide baru dan solusi yang kreatif dari dosen serta mendorong dosen untuk mempelajari dan mempraktikan ilmu baru yang dapat meningkatkan kompetensi dosen.

\subsection{Iklim Organisasi terhadap Kompetensi Dosen}

Diketahui bahwa nilai signifikansi iklim organisasi terhadap kompetensi dosen pada taraf kepercayaan 95\% sebesar 0,043.

\section{Tabel 2}

Uji Regresi Iklim Organisasi Terhadap Kompetensi Dosen

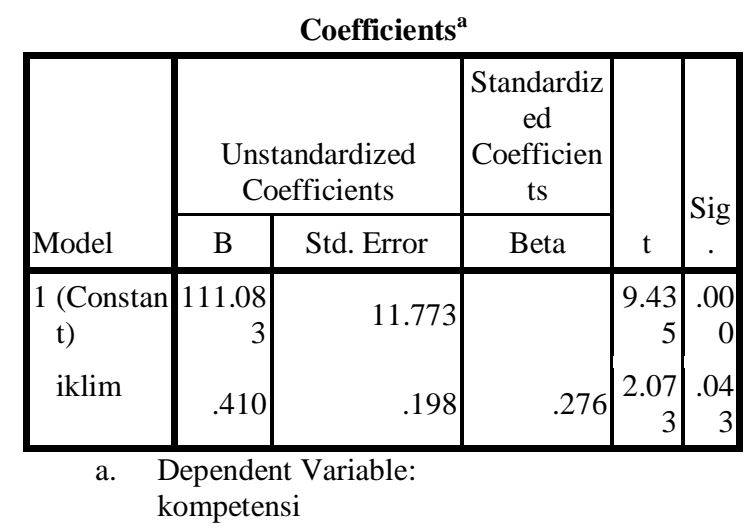

\begin{tabular}{|l|c|c|c|c|}
\multicolumn{5}{|c|}{ Model Summary } \\
\hline Model & $\mathrm{R}$ & $\begin{array}{c}\mathrm{R} \\
\text { Squar } \\
\mathrm{e}\end{array}$ & $\begin{array}{c}\text { Adjust } \\
\text { ed R } \\
\text { Square }\end{array}$ & $\begin{array}{c}\text { Std. Error of the } \\
\text { Estimate }\end{array}$ \\
\hline 1 & $.276^{\mathrm{a}}$ & .076 & .059 & 11.23254 \\
\hline
\end{tabular}

a. Predictors: (Constant), iklim

Sumber : Data Primer, diolah 2019

Hal ini menunjukkan nilai $\mathrm{Sig}=0,043<\alpha=0,05$. Dengan demikian $\mathrm{H}_{0}$ ditolak yang berarti terdapat pengaruh signifikan iklim organisasi terhadap kompetensi dosen. Besarnya keeratan hubungan iklim organisasi terhadap kompetensi dosen sebesar 0,276 yang berarti hubungan lemah.

Besarnya pengaruh iklim organisasi terhadap kompetensi dosen dapat dilihat dari besarnya nilai adjusted $R$ square yang terdapat pada tabel model summery yaitu sebesar 0,059. Hal ini menunjukkan bahwa kontribusi atau sumbangan pengaruh iklim organisasi terhadap kompetensi dosen adalah sebesar 5,9\%, sementara sisanya 94,1\% merupakan kontribusi dari variabel-variabel lain. Iklim organisasi yang kondusif dan nyaman akan berpengaruh terhadap kompetensi dosen yang baik. Namun, jika Sekolah Tinggi tidak mampu menciptkan 
iklim organisasi yang nyaman dan kondusif maka kompetensi dosen akan tidak meningkat.

Hasil penelitian ini, didukung dari penelitian Wahono (2006) yang menyatakan ada pengaruh yang signifikan iklim organisasi sekolah terhadap kompetensi. Meningkatkan kompetensi dosen di Sekolah Tinggi dapat melalui dimensi dukungan (Support). Dukungan merupakan perasaan percaya dan saling mendukung yang terus berlangsung diantara anggota kelompok kerja. Dosen merasa dukungan tinggi apabila mereka bagian tim yang berfungsi dengan baik dan merasa memperoleh bantuan dari atasannya atau rekan kerja, jika mengalami kesulitan dalam menjalankan tugas. Dosen merasa dukungan rendah, apabila dosen merasa terisolasi atau tersisih sendiri.

Selain itu, perlu memperhatikan pemberian penghargaan bagi karya terbaik dosen. Penghargaan hendaknya diberikan sesegera mungkin dan konsisten serta diarahkan untuk memberi rasa kebanggaan. Penghargaan dapat mempertahankan motivasi dan menstimulasi dosen untuk menghasilkan prestasi. Dengan adanya iklim organisasi yang tercipta secara baik dan kondusif akan menghasilkan interaksi yang efektif sehingga akan mendorong dosen untuk mengembangkan dan meningkatkan kompetensi yang dimilikinya. Iklim organisasi dapat diciptakan oleh pemimpin maupun oleh sesama rekan dosen.

\subsection{Kepemimpinan Transformasional terhadap Kinerja Dosen}

Pada bagian Coefficients diketahui bahwa nilai signifikansi kepemimpinan transformasional terhadap kinerja dosen pada taraf kepercayaan $95 \%$ sebesar 0,023 . Hal ini menunjukkan nilai $\mathrm{Sig}=0,023<\alpha=0,05$. Dengan demikian $\mathrm{H}_{0}$ ditolak yang berarti terdapat pengaruh signifikan kepemimpinan transformasional terhadap kinerja dosen. Besarnya keeratan hubungan kepemimpinan transformasional terhadap kinerja dosen sebesar 0,309 yang berarti hubungan lemah.

Besarnya pengaruh kepemimpinan transformasional terhadap kinerja dosen dapat dilihat dari besarnya nilai adjusted $R$ square yang terdapat pada tabel model summery yaitu sebesar 0,078 .

\section{Tabel 3.}

Uji Regresi Kepemimpinan Transformasional Terhadap Kinerja Dosen

\begin{tabular}{|c|c|c|c|c|c|}
\hline \multirow[b]{3}{*}{ Model } & \multicolumn{4}{|c|}{ Coefficients $^{\mathbf{a}}$} & \\
\hline & \multicolumn{2}{|c|}{$\begin{array}{l}\text { Unstandardized } \\
\text { Coefficients }\end{array}$} & \multirow{2}{*}{$\begin{array}{c}\begin{array}{c}\text { Standardized } \\
\text { Coefficients }\end{array} \\
\text { Beta }\end{array}$} & \multirow[b]{2}{*}{$\mathrm{t}$} & \multirow[b]{2}{*}{ Sig. } \\
\hline & B & $\begin{array}{l}\text { Std. } \\
\text { Error }\end{array}$ & & & \\
\hline $1 \quad($ Constant $)$ & 30.144 & 11.665 & & 2.584 & .013 \\
\hline kepemimpinan & .590 & .252 & .309 & 2.339 & .023 \\
\hline
\end{tabular}

$$
\text { Model Summary }
$$

\begin{tabular}{|l|c|r|r|c|}
\hline Model & R & R Square & $\begin{array}{c}\text { Adjusted } \\
\mathrm{R} \\
\text { Square }\end{array}$ & $\begin{array}{c}\text { Std. Error of the } \\
\text { Estimate }\end{array}$ \\
\hline 1 & $.309^{\mathrm{a}}$ & .095 & .078 & 11.88603 \\
\hline
\end{tabular}

a. Predictors: (Constant),

kepemimpinan

Sumber : Data Primer, diolah 2019

Hal ini menunjukkan bahwa kontribusi atau sumbangan pengaruh kepemimpinan transformasional terhadap kinerja dosen adalah sebesar 7,8\%, sementara sisanya $92,2 \%$ merupakan kontribusi dari variabel-variabel lain. Hal ini berarti jika kepemimpinan transformasional ketua baik maka kinerja dosen akan baik. Namun, jika kepemimpinan transformasional ketua tidak baik maka kinerja dosen akan tidak baik.

Kepemimpinan transformasional ketua di Sekolah Tinggi LLDIKTI Wilayah XIV Kabupaten Jayawijaya pada prinsipnya sudah dirasakan oleh dosen, namun belum maksimal, seperti pemimpin kurang memperhatikan makna pekerjaan dosen, 
pemimpin membagi tugas kelembagaan tidak berdasarkan proporsional, dan pemimpin kurang memperhatikan kebutuhan dosen untuk kelancaran melakukan pengajaran, penelitian dan pengabdian kepada masyarakat. Kurang maksimalnya pemimpin menerapkan kepemimpinan transformasional menjadikan dosen di Sekolah Tinggi LLDIKTI Wilayah XIV Kabupaten Jayawijaya kurang termotivasi dalam melakukan kinerja khususnya dalam penelitian dan pengabdian kepada masyarakat.

Pemimpin transformasional dapat membawa perubahan pada kinerja dosen yang cukup tinggi. Untuk dapat meningkatkan kinerja dosen, pemimpin transformasional dapat menerapkan beberapa metode yaitu (Dubrin, 2005)

1) Mengubah kultur organisasi. Ini berarti bahwa nilai, sikap, dan bahkan atmosfer kampus diubah. Perubahan paling umum adalah mengubah kultur dari kultur birokratis, kaku dan sedikit mengambil resiko menjadi kultur dimana dosen bisa lebih bergerak untuk melakukan penelitian dan pengabdian kepada masyarakat dan tidak terlalu dibatasi oleh aturan maupun regulasi.

2) Meningkatkan kesadaran dosen tentang imbalan. Pemimpin transformasional mampu membuat dosen sadar akan arti penting imbalan tertentu jika dosen dapat meningkatkan kinerjanya dan bagaimana cara mendapatkan imbalan.

3) Membantu dosen tidak sekedar mengejar kepentingan diri. Pemimpin transformasional membantu dosen untuk melihat pada gambaran yang lebih besar demi kebaikan tim dan organisasi. Sedikit demi sedikit pemimpin membuat dosen menyadari bahwa tindakan dosen memberi kontribusi pada tujuan yang lebih luas ketimbang sekedar memenuhi kepentingan diri sendiri.

4) Membantu dosen mencari pemenuhan diri. Pemimpin transformasional membantu dosen untuk tidak sekedar berfokus pada kesuksesan kecil-kecilan, tetapi juga pada usaha mencari pemenuhan diri.

5) Memberi pemahaman kepada dosen tentang keadaan urgen. Untuk menciptakan transformasi, pemimpin mengumpulkan dosen dan melibatkan dosen dalam diskusi urgensi perubahan.

6) Mengejar kejayaan. Tindakan transformasional tertinggi adalah membuat dosen bersemangat untuk melakukan kerja keras demi kebesaran dan kejayaan kampus.

Selain itu, pemimpin dapat menerapkan salah satu dimensi kepemimpinan transformasional yaitu Intellectual Stimulation, yaitu pemimpin yang mempraktikkan inovasi-inovasi. Sikap dan perilaku kepemimpinan didasarkan pada ilmu pengetahuan yang berkembang dan secara intelektual pemimpin mampu menerjemahkan dalam bentuk kinerja yang produktif. Dalam hal ini, pemimpin transformasional mempengaruhi dosen dengan berbagai metode sehingga dosen mampu meningkatkan kinerjannya.

\subsection{Iklim Organisasi terhadap terhadap Kinerja Dosen}

Pada bagian Coefficients diketahui bahwa nilai signifikansi iklim organisasi terhadap kinerja dosen pada taraf kepercayaan $95 \%$ sebesar 0,115. Hal ini menunjukkan nilai $\mathrm{Sig}=0,115>\alpha=0,05$. Dengan demikian $\mathrm{H}_{0}$ diterima yang berarti tidak terdapat pengaruh signifikan iklim organisasi terhadap kinerja dosen. Besarnya keeratan hubungan iklim organisasi terhadap 
kinerja dosen sebesar 0,217 yang berarti hubungan lemah.Besarnya pengaruh iklim organisasi terhadap kinerja dosen dapat dilihat dari besarnya nilai adjusted $R$ square yang terdapat pada tabel model summery yaitu sebesar 0,029.

\section{Tabel 4}

Uji Regresi Iklim Organisasi Terhadap Kinerja Dosen

Coefficients $^{\mathrm{a}}$

\begin{tabular}{|c|c|c|c|c|c|}
\hline \multirow[b]{2}{*}{ Model } & \multicolumn{2}{|c|}{$\begin{array}{l}\text { Unstandardized } \\
\text { Coefficients }\end{array}$} & \multirow{2}{*}{$\begin{array}{c}\begin{array}{c}\text { Standardized } \\
\text { Coefficients }\end{array} \\
\text { Beta }\end{array}$} & \multirow[b]{2}{*}{$\mathrm{t}$} & \\
\hline & B & $\begin{array}{l}\text { Std. } \\
\text { Error }\end{array}$ & & & Sig. \\
\hline (Constant) & 36.819 & 12.784 & & 2.880 & .006 \\
\hline iklim & .345 & .215 & .217 & 1.605 & .115 \\
\hline
\end{tabular}

Model Summary

\begin{tabular}{|l|r|r|r|r|}
\hline Model & \multicolumn{1}{|c|}{$\mathrm{R}$} & R Square & $\begin{array}{r}\text { Adjusted } \\
\text { R Square }\end{array}$ & $\begin{array}{r}\text { Std. Error of the } \\
\text { Estimate }\end{array}$ \\
\hline 1 & $.217^{\mathrm{a}}$ & .047 & .029 & 12.19724 \\
\hline
\end{tabular}

Sumber : Data Primer, diolah 2019

Hal ini menunjukkan bahwa kontribusi atau sumbangan pengaruh iklim organisasi terhadap kinerja dosen adalah sebesar 2,9\%, sementara sisanya $97,1 \%$ merupakan kontribusi dari variabel-variabel lain.

Iklim organisasi tidak berpengaruh terhadap kinerja dosen dikarenakan iklim organisasi yang dirasakan oleh dosen di setiap Sekolah Tinggi belum mampu meningkatkan kinerja dosen khususnya dalam penelitian dan pengabdian kepada masyarakat. Dalam hal ini, Sekolah Tinggi LLDIKTI Wilayah XIV yang berada di Kabupaten Jayawijaya tidak dapat meningkatkan kinerja dosen dengan meningkatkan iklim organisasi. Sekalipun iklim yang dibangun oleh setiap Sekolah
Tinggi nyaman dan kondusif, tetapi jika dosen itu sendiri tidak mempunyai kemauan dan kemampuan yang baik dalam melaksankan tri dharma Perguruan Tinngi khususnya dalam penelitian dan pengabdian kepada masyarakat maka cenderung kinerja dosen akan rendah. Hasil penelitian ini dapat saja beralasan, dikarenakan iklim organisasi adalah salah satu faktor yang turut memberi andil dalam kinerja dosen. Besarnya pengaruh iklim organisasi terhadap kinerja dosen relatif kecil yaitu 2,9\%.

Kinerja dosen tidak hanya dipengaruhi oleh iklim organisasi, namun ada $97,1 \%$ dipengaruhi oleh faktor lain. Faktor lain yang mempengaruhi kinerja dosen menurut Gibson (2008) yaitu faktor dari diri (kemampuan dan keterampilan, latar belakang, demografis), faktor psikologi (persepsi, sikap, kepribadian, motivasi, kepuasan kerja, stres kerja), dan faktor organisasi (kepemimpinan, kompensasi, konflik, kekuasaan, struktur organnisasi, desain pekerjaan, desain organisasi, karir).

\subsection{Kompetensi Dosen terhadap Kinerja Dosen}

Pada bagian Coefficients diketahui bahwa nilai signifikansi kompetensi dosen terhadap kinerja dosen pada taraf kepercayaan $95 \%$ sebesar 0,000 . Hal ini menunjukkan nilai $\mathrm{Sig}=0,000<\alpha=0,05$. Dengan demikian $\mathrm{H}_{0}$ ditolak yang berarti terdapat pengaruh signifikan kompetensi dosen terhadap kinerja dosen. Besarnya keeratan hubungan kompetensi dosen terhadap kinerja dosen sebesar 0,567 yang berarti hubungan sedang. 
Tabel 5

Uji Regresi Kompetensi Dosen Terhadap Kinerja Dosen

Coefficients $^{\mathrm{a}}$

\begin{tabular}{|c|c|c|c|c|c|}
\hline \multirow[b]{2}{*}{ Model } & \multicolumn{2}{|c|}{$\begin{array}{l}\text { Unstandardized } \\
\text { Coefficients }\end{array}$} & \multirow{2}{*}{\begin{tabular}{|c|}
$\begin{array}{c}\text { Standardized } \\
\text { Coefficients }\end{array}$ \\
Beta
\end{tabular}} & \multirow[b]{2}{*}{$\mathrm{t}$} & \multirow[b]{2}{*}{ Sig. } \\
\hline & B & $\begin{array}{l}\text { Std. } \\
\text { Error }\end{array}$ & & & \\
\hline $1 \quad$ (Constant) & 24.853 & 16.580 & & -1.499 & .140 \\
\hline kompetensi & .606 & .122 & .567 & 4.965 & .000 \\
\hline
\end{tabular}

\begin{tabular}{|l|l|r|r|r|}
\hline Model & R & R Square & $\begin{array}{l}\text { Adjusted } \\
\text { R Square }\end{array}$ & Std. Error of the Estimate \\
\hline 1 & $.567^{\mathrm{a}}$ & .322 & .309 & 10.29230 \\
\hline
\end{tabular}
a. Predictors: (Constant),
kompetensi

Sumber : Data Primer, diolah 2019

Besarnya pengaruh kompetensi dosen terhadap kinerja dosen dapat dilihat dari besarnya nilai adjusted $R$ square yang terdapat pada tabel model summery yaitu sebesar 0,309. Hal ini menunjukkan bahwa kontribusi atau sumbangan pengaruh kompetensi dosen terhadap kinerja dosen adalah sebesar $30,9 \%$, sementara sisanya $69,1 \%$ merupakan kontribusi dari variabelvariabel lain.

Hal ini berarti bahwa baik tidaknya kinerja dosen berpengaruh terhadap baik tidaknya kompetensi dosen dan sebaliknya jika kompetensi dosen kurang baik maka kinerja dosen juga kurang baik. Besarnya keeratan hubungan kompetensi dosen terhadap kinerja dosen sebesar 0,567 yang berarti hubungan sedang. Hasil penelitian ini sependapat dengan Aththaariq (2014) menjelaskan bahwa kompetensi dosen mempunyai pengaruh yang signifikan terhadap kinerja dosen.

Kompetensi dosen yang ada di Sekolah Tinggi LLDIKTI Wilayah XIV yang berada di Kabupaten Jayawijaya memiliki nilai rata-rata 135,28. Hal ini disebabkan antara lain yaitu: 1) Dosen menggunakan sedikit sumber belajar/buku referensi dalam pembelajaran, 2) Dosen belum mampu menyajikan/mempubikasikan hasil penelitian di tingkat jurusan, perguruan tinggi, nasional bahkan internasional, 3) Dosen belum mampu merancang, melaksanakan dan menyusun laporan Pengabdian kepada Masyarakat (PkM) secara mandiri maupun kelompok, 4) Dosen kurang melibatkan masyarakat dalam kegiatan tri darma Perguruan Tinggi, dan 5) Dosen belum rutin malakukan kegiatan pengabdian kepada masyarakat setiap semester berjalan.

Kompetensi dosen merupakan bagian dari pengetahuan, keterampilan, dan kemampuan yang dimiliki oleh dosen. Kompetensi dosen merupakan modal awal dosen melakukan kinerjannya. Untuk meningkatkan kinerja dosen maka kompetensi dosen harus ditingkatkan.

\subsection{Kepemimpinan Transformasional Melalui Kompetensi Dosen Terhadap Kinerja Dosen}

Pengujian ini dilakukan dengan melihat pengaruh langsung dan tidak langsung kepemimpinan transformasional melalui kompetensi dosen terhadap kinerja dosen. Tahap pertama adalah melihat pengaruh langsung yang diberikan kepemimpinan transformasional terhadap kinerja dosen yaitu 0,309. Tahap kedua yaitu dengan melihat pengaruh tidak langsung kepemimpinan transformasional terhadap kinerja dosen melalui kompetensi dosen yaitu dengan mengalikan antara nilai beta kepemimpinan transformasional terhadap kompetensi dosen dengan nilai beta kompetensi dosen terhadap kinerja dosen yaitu: $0,281 \times 0,567=0,159$. Tahap ketiga yaitu menghitung pengaruh total yang diberikan, dengan menjumlahkan pengaruh 
langsung dengan pengaruh tidak langsung yaitu: $0,309+0,159=0,468$.

Berdasarkan hasil perhitungan di atas diketahui bahwa nilai pengaruh langsung sebesar 0,309 dan nilai pengaruh tidak langsung sebesar 0,159 yang berarti bahwa nilai pengaruh langsung lebih besar dibandingkan dengan nilai pengaruh tidak langsung. Dengan demikian $\mathrm{H}_{0}$ diterima, karena hasil menunjukkan bahwa secara tidak langsung kepemimpinan transformasional ketua melalui kompetensi dosen tidak mempunyai pengaruh yang signifikan terhadap kinerja dosen.

Hal ini berarti, pengaruh kepemimpinan transformasional ketua melalui kompetensi dosen terhadap kinerja dosen tidak dapat digeneralisasikan kepada seluruh dosen yang ada di Sekolah Tinggi LLDIKTI Wilayah XIV Kabupaten Jayawijaya. Hasil ini dapat saja beralasan, dikarenakan kepemimpinan transformasional ketua dapat meningkatkan kompetensi dosen, setelah kompetensi dosen ditingkatkan kinerja dosen akan meningkat, namun hal ini hanya berlaku untuk sampel penelitian, sedangkan untuk populasi tidak berlaku. Ketidakberlakuan pada populasi dapat disebabkan beberapa faktor yaitu: 1) kemauan dosen dalam melakukan tri dharma perguruan tinggi kurang walaupun kompetensi dosen mendukung, 2) lingkungan dan keamanan menjadi halangan dosen melakukan tri dharma Perguruan Tinggi walaupun dosen memiliki kompetensi dan kemauan, 3) kepuasan kerja.

\subsection{Iklim Organisasi Melalui Kompetensi Dosen Terhadap Kinerja Dosen.}

Analisis pengaruh iklim organisasi terhadap kinerja dosen melalui kompetensi dosen dapat diketahui dengan mengunakan analisis jalur. Tahap pertama adalah melihat pengaruh langsung yang diberikan iklim organisasi terhadap kinerja dosen yaitu 0,217. Tahap kedua yaitu dengan melihat pengaruh tidak langsung iklim organisasi terhadap kinerja dosen melalui kompetensi dosen yaitu dengan mengalikan antara nilai beta iklim organisasi terhadap kompetensi dosen dengan nilai beta kompetensi dosen terhadap kinerja dosen yaitu: $0,276 \times 0,567=0,156$. Tahap ketiga yaitu menghitung pengaruh total yang diberikan iklim organisasi terhadap kinerja dosen dengan menjumlahkan pengaruh langsung dengan pengaruh tidak langsung yaitu: $0,276+0,156=0,432$.

Berdasarkan hasil perhitungan di atas diketahui bahwa nilai pengaruh langsung sebesar 0,276 dan nilai pengaruh tidak langsung sebesar 0,156 yang berarti bahwa nilai pengaruh langsung lebih besar dibandingkan dengan nilai pengaruh tidak langsung. Dengan demikian $\mathrm{H}_{0}$ diterima, karena hasil menunjukkan bahwa secara tidak langsung iklim organisasi melalui kompetensi dosen tidak mempunyai pengaruh yang signifikan terhadap kinerja dosen.

Hal ini berarti, pengaruh iklim organisasi melalui kompetensi dosen terhadap kinerja dosen tidak dapat digeneralisasikan kepada seluruh dosen yang ada di Sekolah Tinggi LLDIKTI Wilayah XIV Kabupaten Jayawijaya. Dalam hal ini, iklim organisasi Sekolah Tinggi LLDIKTI Wilayah XIV yang berada di Kabupaten Jayawijaya tidak dapat meningkatkan kinerja dosen melalui kompetensi dosen. Sekalipun iklim yang dibangun oleh setiap Sekolah Tinggi nyaman dan kondusif, sehingga kompetensi dosen meningkat, namun jika dosen itu sendiri tidak mempunyai kemauan dalam melaksankan tri dharma Perguruan Tinngi khususnya dalam penelitian dan pengabdian kepada masyarakat maka cenderung kinerja dosen akan rendah. 


\section{KESIMPULAN}

Berdasarkan hasil penelitian dan pembahasan yang telah dipaparkan, maka dapat diambil kesimpulan sebagai berikut:

1. Terdapat pengaruh kepemimpinan transformasional terhadap kompetensi dosen sebesar $6,1 \%$.

2. Terdapat pengaruh iklim organisasi terhadap kompetensi dosen sebesar 5,9\%.

3. Terdapat pengaruh kepemimpinan transformasional terhadap kinerja dosen sebesar 7,8\%.

4. Tidak terdapat pengaruh iklim organisasi terhadap kinerja dosen.

5. Terdapat pengaruh kompetensi dosen terhadap kinerja dosen sebesar 30,9\%.

6. Tidak terdapat pengaruh kepemimpinan transformasional melalui kompetensi dosen terhadap kinerja dosen.

7. Tidak terdapat pengaruh iklim organisasi melalui kompetensi dosen terhadap kinerja dosen.

\section{REFERENSI}

Arwildayanto. 2012. Manajemen Sumber Daya Manusia Perguruan Tinggi; Pendekatan Budaya Kerja Profesional. Gorontalo: Ideas Fublishing.

Aththaariq, Dkk. 2014. Pengaruh Kompetensi Dosen Terhadap Kinerja Dosen di Universitas Trunojoyo Madura. Jurnal Studi Manajemen dan Bisnis Vol 1 No. 1 Tahun 2014. Melalui

<Http://Journal.Trunojoyo.Ac.Id/>

[Akses Tanggal 30 Januari 2019].

Baharun, Hasan. Peningkatan Kompetensi Guru Melalui Sistem Kepemimpinan Kepala Madrasah. Jurnal Ilmu Tarbiyah, Vol. 6 No. 1, Januari 2017. Melalui

<http://ejournal.stitmuhpacitan.ac.id/in dex.php/tajdid/> [Akses Tanggal 30 Januari 2019].
Direktorat Jenderal Kelembagaan Iptek dan Dikti Kementerian Riset, Teknologi dan Pendidikan Tinggi. 2017. Kopertis Wilayah XIV - Papua, Papua Barat, melalui

<https://kelembagaan.ristekdikti.go.id/i ndex.php/kopertis-wilayah-xiv-papuapapua-barat/>[Akses Tanggal 30 Januari 2019].

Dubrin, Andrew J. 2005. Leadership (Terjemahan). Edisi Kedua. Jakarta: Prenada Media

Gibson, J. L, dkk. 2008. Organisasi, Perilaku, Struktur, dan Proses. Jakarta : Binapura Aksara Publisher

Karwati, E. \& Priansa, D. J. 2013. Kinerja dan Profesionalisme Kepala Sekolah Membangun Sekolah yang Bermutu. Bandung: Alfabeta.

Komariah, Aan \& Triatna, Cepi. 2010. Visionary Leadership Menuju Sekolah Efektif. Jakarta: Bumi Aksara.

Luthans, Fred. 2006. Perilaku Organisasi Edisi Sepuluh. Yogyakarta: CV. Andi Offset.

Musfah, Jejen. 2011. Peningkatan Kompetensi Guru: Melalui Pelatihan dan Sumber Belajar Teori dan Praktek. Jakarta: Kencana.

Priansa, Donni Juni. 2014. Kinerja dan Profesionalisme Guru. Bandung: Alfabeta.

Sunyoto, Danang. 2013. Teori, Kuesioner, dan Proses Analisis Data Perilaku Organisasional. Jakarta : PT. Buku Seru. 
WAHANA

Volume 71, Nomor 1, 1 Juni 2019

Supardi. 2013. Kinerja Guru. Jakarta: PT.Raja Grafindo Persada.

Triantoro, Safaria. 2004. Kepemimpinan. Edisi Pertama. Yogyakarta: Graha Ilmu.

Undang-Undang Republik Indonesia Nomor 14 Tahun 2005 Tentang Guru Dan Dosen.

Wahono. 2006. Pengaruh Motivasi Kerja Dan Iklim Organisasi Terhadap
Kompetensi Pengelolaan Kelas Di Sekolah Dasar Kristen Yski Semarang. Jurnal Fokus Ekonomi Vol. 1 No. 2006 : 40 53. Melalui < http://stiepena.ac.id/ $>$ [akses tanggal 28 Januari 2019]

Wibowo. 2007. Manajemen Kinerja. Jakarta: PT. Raja Grafindo Parsada.

Wirawan. 2007. Budaya dan Iklim Organisasi; Teori dan Aplikasi Penelitian. Jakarta. Salemba Empat. 